\title{
Como o esforço do perito de local, em SC, e o BNPG levaram à solução de um homicídio no PR após 10 anos sem suspeitos
}

\author{
O. E. M. V. e R. Penna ${ }^{a, *}$ \\ ${ }^{a}$ Instituto de Criminalística, Instituto Geral de Perícias, Santa Catarina (SC), Brasil \\ *Endereço de e-mail para correspondência: odicsan@gmail.com \\ Recebido em 03/11/2019; Revisado em 15/05/2020; Aceito em 20/05/2020
}

\begin{abstract}
Resumo
Apesar dos esforços dos estados em manter recursos humanos adequados, é cada vez maior a discrepância na relação entre a quantidade de Peritos Criminais e a quantidade de crimes ocorridos no Brasil[1]. O Banco Nacional de Perfis Genéticos (BNPG) é uma ferramenta que permite diminuir este desequilíbrio, viabilizando a determinação de autores, quer seja em crimes que estejam em investigação, quer seja nos chamados casos "frios" (aqueles sem suspeitos de autoria). Este artigo apresenta o exemplo de conduta de um Perito de Local que, mesmo sem requisição, vislumbrou a importância da coleta de material biológico no hospital, de uma menina estuprada e jogada em uma linha de trem - para ser atropelada e morrer, em Santa Catarina. Este procedimento, além de culminar na confirmação e condenação do autor, permitiu - via BNPG - fazer a indicação do mesmo indivíduo como o responsável pelo estupro e homicídio de outra vítima, no PR, passados 10 anos, sem a existência de nenhum suspeito. Este trabalho demonstra, portanto, como o labor do Perito Criminal de Local impacta diretamente na determinação de autoria e materialidade de um crime, devendo estes sempre se esmerarem para atingir seus objetivos.
\end{abstract}

Palavras-Chave: Coleta; Estupro; Homicídio; BNPG; Requisição;

\begin{abstract}
Despite the states' efforts to maintain reasonable human resource levels, the discrepancy between the rate of available Crime Scene Investigators versus crimes occurrences in Brazil just grows. The Brazilian Codis (National Database of Genetic Profiles - BNPG) is a useful tool to balance, performing the appropriate determination of authorship in open or cold cases (when no suspects are known). This article presents the efforts of a CSI whom, by his own, gathered genetic material in a hospital from a victim of rape and attempted murder, (threw in a train to die) in Santa Catarina state. Besides the criminal's identification and sentence, thanks to the evidence collected, the BNPG was able to link him to another victim of rape and homicide in Parana state, 10 years later, without any clue of authorship. The State Police had already gave up investigating. This article shows how Crime Scene Investigator's activities reflects directly on crime resolution, authorship and materiality reveal, requiring his compliance to overwhelm his duties whenever needed.
\end{abstract}

Keywords: DNA collection; Rape; Homicide; Codis; Requisition.

\section{INTRODUÇÃO}

No dia das crianças de 2013, uma chamada às 5h30m: uma garota estuprada e atropelada por um trem em Mafra, SC. Esse é o começo da história que culminou na condenação de E. G. da C., bem como pelo seu apontamento no estupro e homicídio de A. de F. Q., em Curitiba, PR, passados 10 anos sem nenhum suspeito[2].

\section{PROCEDIMENTOS}

\subsection{Primeiros passos}

O acionamento inicial informava que uma "menina" fora estuprada e jogada "no trem". O cenário começa a se caracterizar logo na chegada ao local: descobre-se que ali não existia mais trem, a Polícia Militar (PM) fizera um isolamento amplo, a Polícia Civil (PC) já houvera passado, 


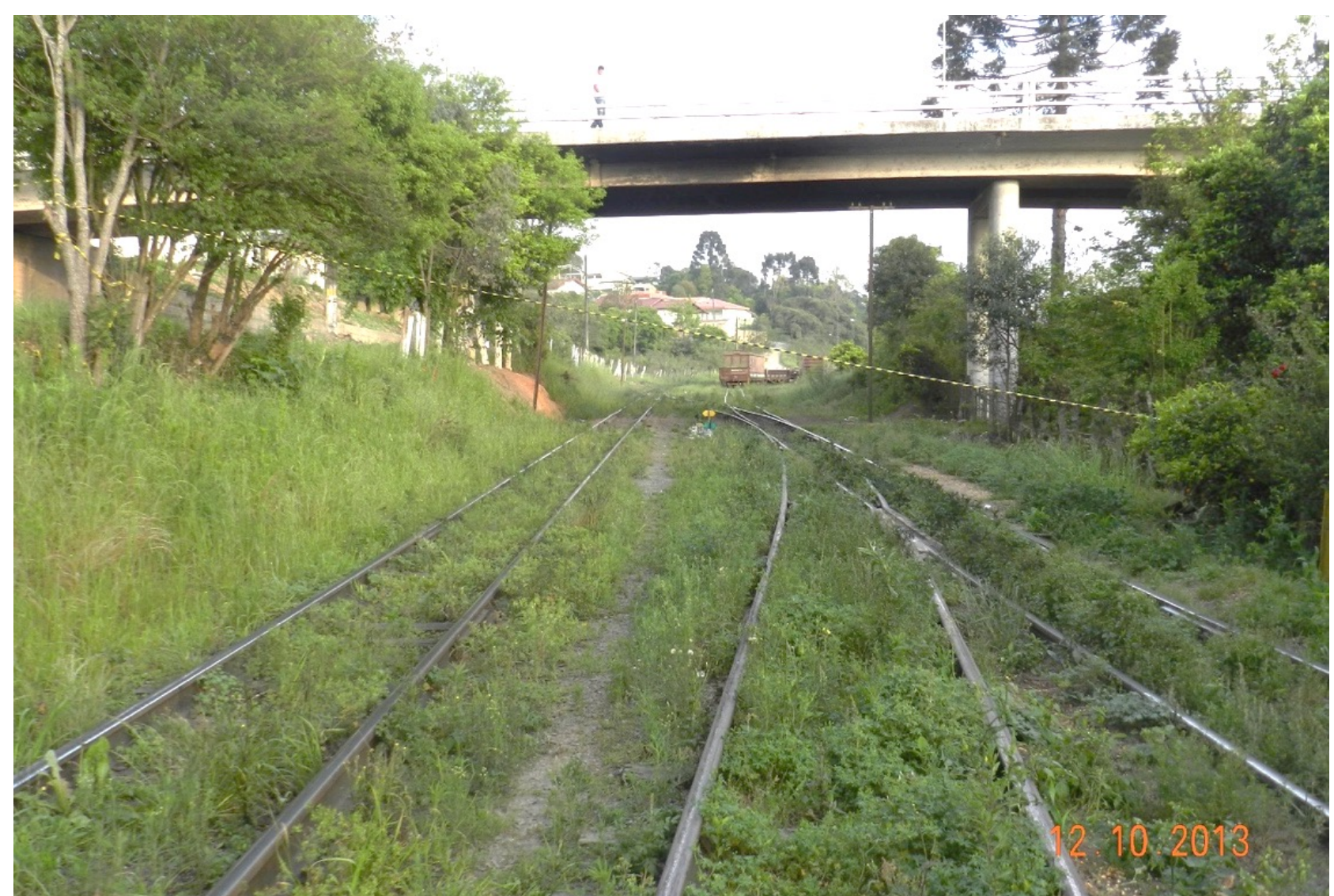

Imagem 1 -Visão parcial do local

o Corpo de Bombeiros (CBMSC) fizera seu atendimento e o Instituto de Medicina Legal (IML/IGP) não fora acionado.

Como assim? E o corpo, quem levaria?

Ninguém, pois não havia corpo! L. C. de L. [3] estava viva - tendo sido levada ao hospital.

As informações eram desencontradas. A Guarnição (GU) PM que ali se apresentava isolando o perímetro não era a mesma do atendimento inicial, nenhum dos presentes havia, de fato, visto a vítima, o local de resgate pelos Bombeiros era incondizente com o sítio de atropelamento, ninguém sabia qual era a direção e sentido do trem, a vítima teria narrado situações contraditórias sobre os fatos: ora dizia que correra e fora atropelada pelo trem, ora que fora arremessada para ser morta...

\subsection{Desenvolvimento}

Como é cediço, uma das maneiras da busca por vestígios é a utilização do método por varredura [4] e, assim, do ponto de resgate da vítima, iniciaram-se os procedimentos em linha. Começando com manchas de sangue, à medida que caminhava-se ao longo das 2 linhas

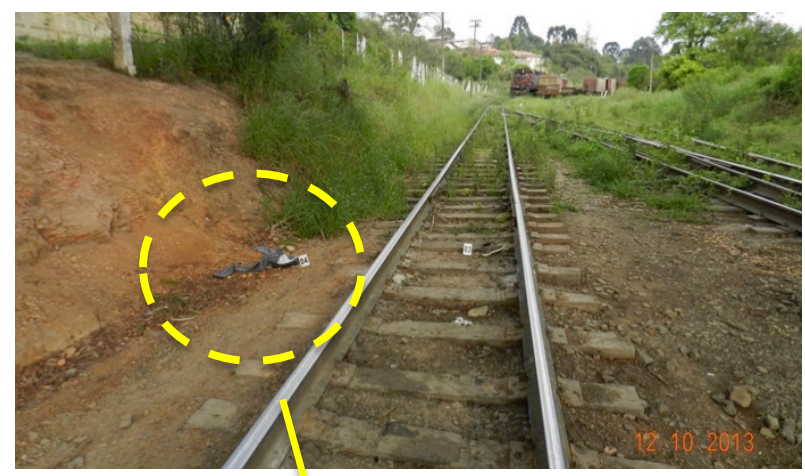

Imagem 2 - Localização de vestimenta

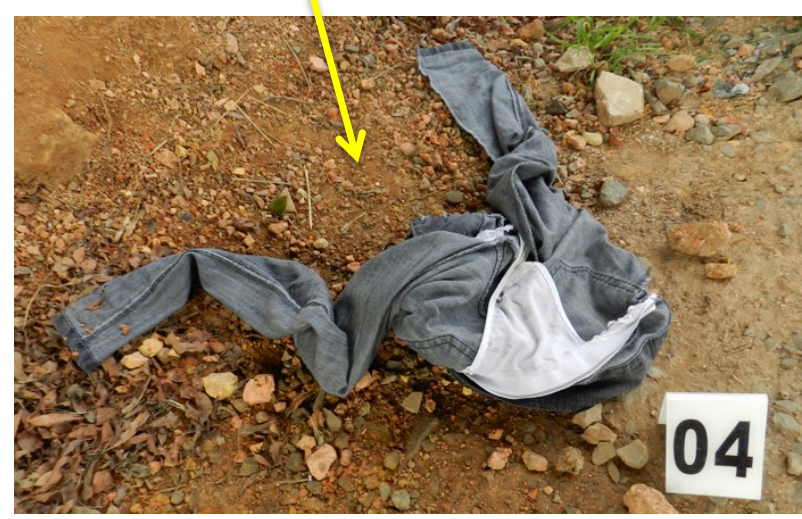

Imagem 3 - Visão aproximada de vestimenta férreas ali existentes foi sendo encontrando calçado, calça, calcinha, mochila, uma meia entre arbustos - dentro desta, seu pé esquerdo - e um dos membros superiores. 


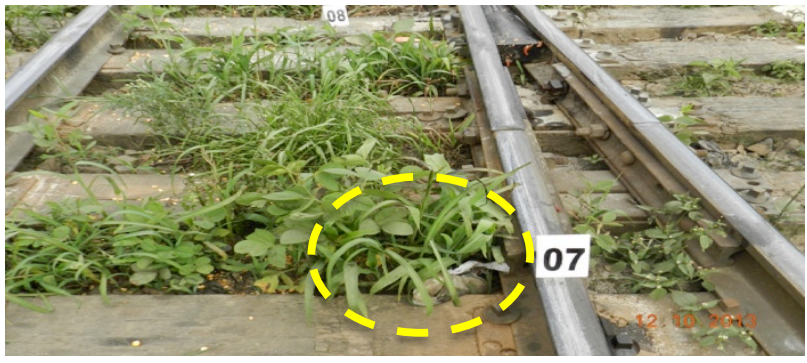

Imagem 4 - Localização de pé esquerdo

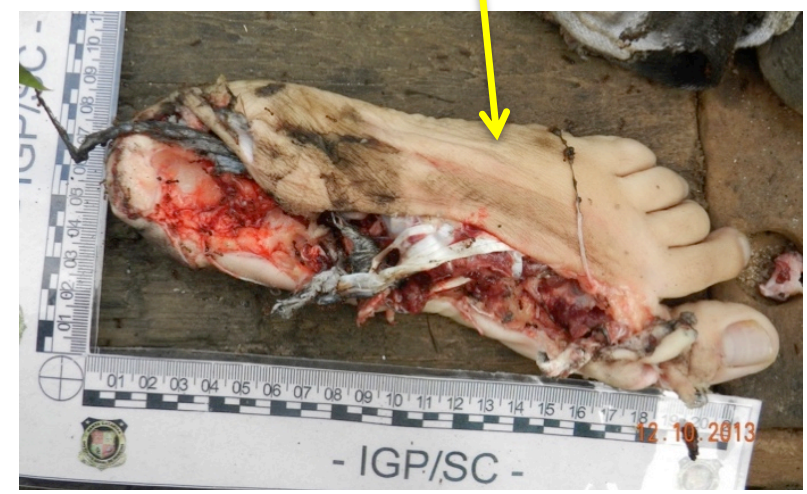

Imagem 5 - Visão aproximada de pé esquerdo

Após horas de labuta, por volta das $13 \mathrm{~h}$, finalizaram-se os trabalhos no sítio. Os únicos vestígios concretos que pudessem tentar contribuir para se chegar à autoria eram: uma calcinha e a mão da vítima, neste último, onde poderia tentar ser feita a extração de material sub-ungueal[5].

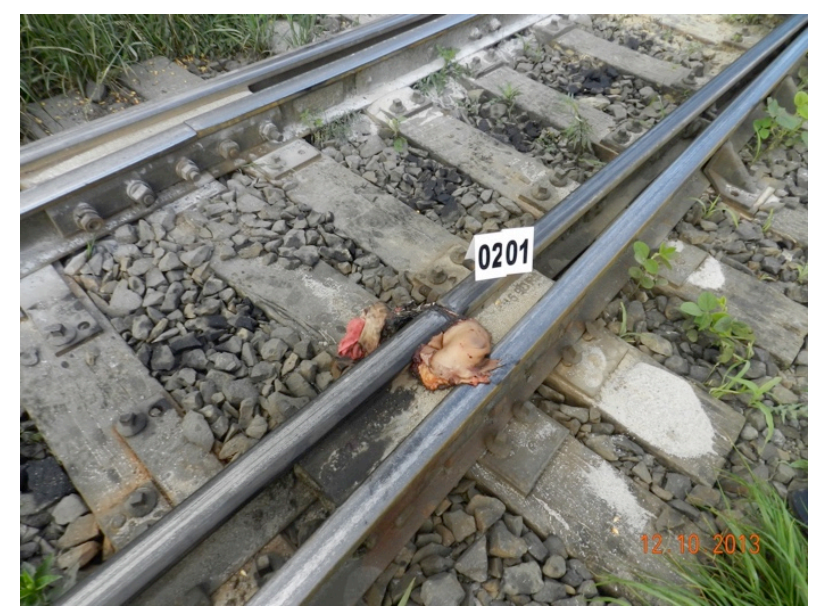

Imagem 6 - Localização de mão esquerda

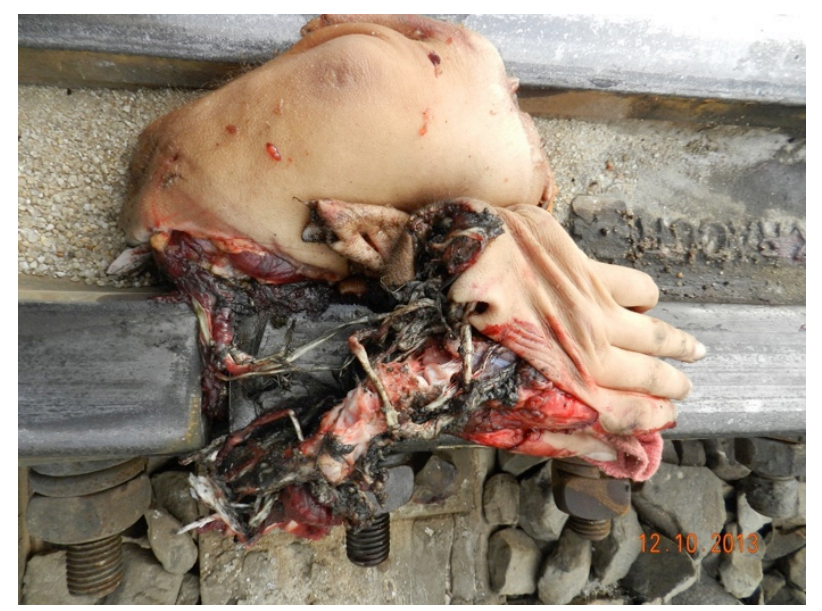

Imagem 7 - Visão aproximada de mão esquerda

\subsection{Questionamento}

Aqui chega-se ao grande questionamento deste deste trabalho: até onde vai a atribuição de um Perito, em especial, o de local?

Já que a Autoridade Policial não fez nenhuma outra requisição, cabe a nós irmos atrás de locais relacionados?

É cabível uma ação em busca de dados a partir dos quais o Perito transforme isso em conhecimento[6] e, como bem sabemos, um vestígio se torne evidência, com vistas a ser prova em um processo?

É função da criminalística extenuar meios pela busca de autoria e materialidade, incluindo fontes negadas?

Considerando o tempo que o Laudo Pericial[7] chega às mãos do Delegado e que as horas pós fato são cruciais no apontamento de autoria, como podemos auxiliar, especialmente em contextos sensíveis?

\subsection{Continuidade e persistência}

De volta ao caso, esgotou-se o sítio e retornou-se à Base. Surgiu, então, o "pensar além, fazer a mais". Deslocou-se ao hospital, a fim de descobrir se ela já houvera sido higienizada para solicitar a coleta de material anal e vaginal - tendo aqui se dado o trabalho mais hercúleo.

No hospital, o médico da UTI, onde a vítima se encontrava, recusou-se a falar conosco, enviando uma Enfermeira como interlocutora. Perguntamos qual era o estado da vítima e fomos informados que ela estava viva, em choque, sedada, e com os membros superiores e parte do inferior esquerdo amputados, além de diversas escoriações, mas ainda não fora localmente higienizada.

Explicamos a importância da coleta de material para envio ao laboratório e pedimos que ela retransmitisse esse cenário ao Médico, ao que ela prontamente atendeu, retornando à UTI. Ele, ainda sem se reportar diretamente a nós, mandou informar que só permitiria tal procedimento, se fosse conduzido pelo Médico Legista. Informamos, via Enfermeira, que o nosso servidor estava de licença nojo e não tínhamos outro à disposição, solicitando mais uma vez falar diretamente com ele.

Nesta terceira tentativa ele saiu da sala da Unidade e veio ouvir nossos argumentos. Ainda irredutível, disse que dispensaria o Médico Legista, desde que a coleta de material fosse realizada na presença do Delegado. Entramos em contato com o Delegado Regional que, para piora do cenário, encontrava-se fora da cidade por problemas particulares. Diante da gravidade dos fatos, a Autoridade Policial chegou a nos orientar para que conversássemos novamente com o Médico e, se este novamente se recusasse a permitir a coleta - impondo óbices, deveríamos dar voz de prisão e solicitar apoio da PM para escolta à Delegacia. 
Voltando mais uma vez, tentamos dissuadir o médico, ao que ele finalmente concordou que as Enfermeiras fizessem a coleta. Com vistas a garantir a cadeia de custódia, tal procedimento deveria ser acompanhado por nós. Contudo, ele não abria mão de uma requisição por escrito da Delegacia.

Por volta das $15 \mathrm{~h} 30 \mathrm{~m}, 10 \mathrm{~h}$ após o início dos trabalhos, conseguimos acesso à UTI e acompanhamos a coleta de 5 $s w a b s$, da região anal e vaginal da vítima.

O material foi encaminhado ao Instituto de Análises Forenses (IAF/IGP), seguindo escorreita cadeia de custódia e atendimento às exigências protocolares. Isto permitiu seu processamento e análise, tendo sido reportado que parte dos swabs possuía condições de comparação.

\section{O SUSPEITO E O LABORATÓRIO}

Com o passar dos meses, graças a um notável trabalho de investigação, chegou-se à pessoa de E. G. da C., que negava tanto o estupro quanto a tentativa de homicídio. A adolescente, após receber alta do hospital, tampouco se lembrava de algo do ocorrido: houvera perdido a memória recente, a chamada amnésia dissociativa[8], num mecanismo de o cérebro bloquear eventos traumáticos, desta forma, pouco podendo ajudar na elucidação dos fatos.

Ele, certo que não havia prova alguma de sua atuação nos crimes (e de fato, fora o material coletado no hospital, havia apenas referências meramente circunstanciais de sua atuação no crime), e amparado pelo seu advogado, consentiu em doar material para comparação.

\subsection{Resultado}

Apesar de apenas parte do material ter condições, houve plena convergência (MATCH) nas amostras, quando da comparação com o material cedido pelo então suspeito. Com isso, o Tribunal do Júri, em 2015 (3 anos após os fatos) condenou E. G. da C a cerca de 30 anos pelos crimes de estupro e tentativa de homicídio[9], consubstanciado, basicamente, no material colhido na UTI do hospital, graças aos esforços empenhados.

\subsection{A Surpresa e o BNPG}

Agora vem a segunda parte crucial deste trabalho. Os procedimentos de coleta, acondicionamento e encaminhamento da amostra do então suspeito foram de tal forma escorreitos (campo, custódia, laboratório), que atenderam às exigências (mais restritivas) para sua introdução na base nacional. Assim, em 2018, a equipe do IAF fez a inserção do perfil genético no Banco Nacional de Perfis Genéticos (BNPG). A grata surpresa veio por meio da comunicação do gerente do Banco de Dados no Estado,
Dr. Clineu Uehara, já em 2019: o perfil do indivíduo havia convergido com a amostra coletada no crime de homicídio de uma mulher, em 2009, na cidade de Curitiba! Crime este que até aquele momento não possuía suspeito algum, a polícia daquele estado já não possuía mais meios de continuar a investigação e que, se não fosse o trabalho da equipe paranaense em conjunto com a catarinense, somados ao software de comparação, seria mais um na estatística dos crimes não solucionados.

\section{CONCLUSÕES}

Ratifique-se que o local imediato do crime para o qual houve o acionamento foi tão somente a linha férrea e imediações. Logo, não havia requisição para a busca por vestígios e evidências em outros locais, notadamente, o hospital. Contudo, se não fosse essa iniciativa de se buscar a coleta de material genético junto à vítima - algo não trivial - talvez não tivéssemos o cenário aqui apresentado.

Portanto, graças ao esforço inicial de um Perito de Local, agregado ao de inúmeros outros profissionais igualmente dedicados, em suas respectivas áreas de atuação, foi possível a indicação da provável autoria (ainda $\underline{\text { sem julgamento) de um estupro e homicídio } 10 \text { anos após }}$ os fatos, que, se fosse de outra forma, nunca teria ocorrido.

Assim, em nosso humilde entender, e com o devido respeito às opiniões adversas, sim, devemos SEMPRE, dentro da peculiaridade de cada realidade regional e cenários periciais díspares, fazer o que for possível, ainda que precisemos ultrapassar algumas fronteiras não claras de nossas atribuições, para que através da busca de vestígios, os transformemos em evidências, com vistas ao visum et repertum (ver e repetir).

Como muito bem externado e, parafraseando alhures, "Perito observa, faz análises, testa hipóteses, infere conclusões, aplica ciências e seus conceitos, sendo que a criminalística é a união de todas elas (...) onde o perito pode atuar, e isto tudo vai muito além do ver e repetir." $\mathrm{E}$ foi isso que sempre buscamos em nossos casos - neste, em especial.

Seguros, citamos como empenho rotineiro, os procedimentos em uma ocorrência, de roubo e tentativa de homicídio, resultando então no segundo (e únicos casos criminais no estado de SC) evento frutífero de convergência genética [9].

Destarte, quando um Perito tiver a oportunidade de ir além, saindo da sua zona de conforto e seguindo a devida cadeia de custódia, pode se proporcionar um ótimo material à equipe de laboratório para análise e inserção no BNPG [10], com vistas à resolução de outros inúmeros crimes ainda sem autoria definida - auxiliando a devida persecução penal. 


\section{AGRADECIMENTOS}

Gostaríamos de agradecer a todos os envolvidos, em especial à equipe de DNA do IAF (Peritos Bioquímicos Clineu J. S. Uehara, Sandra R. R. Torres, Kelly R. Lobato, e Alessandra R. Koehler), bem como ao Perito Criminal Michael K. Kolb e aos Auxiliares Criminalísticos, do Núcleo Regional de Mafra/SC pelo sempre profissionalismo demonstrado.

Agradecemos ainda o XXV CNC de Criminalística pela outorga do prêmio recebido.

\section{REFERÊNCIAS BIBLIOGRÁFICAS}

[1] GODINHO, Neide Maria de Oliveira. Banco de dados de DNA: uma ferramenta a serviço da justiça. Acessado em 10/07/2019. Disponível em:

https://doi.org/10.29377/rebesp.v7i2.193

[2] Assassinato é solucionado quase 10 anos depois com ajuda de banco genético. Acessado em: 29/06/2019. Disponivel em: https://g1.globo.com/sc/santacatarina/noticia/2019/06/27/assassinato-em-sc-esolucionado-quase-10-anos-depois-com-ajuda-de-bancogenetico.ghtml

[3] Adolescente fica gravemente ferida após ser atropelada por trem no Norte. Acessado em 09/07/19. Disponivel em: http://g1.globo.com/sc/santacatarina/noticia/2013/10/adolescente-fica-gravementeferida-apos-ser-atropelada-por-trem-no-norte.html
[4] SILVA Netto, Amilcar da Serra e; Manual de atendimento a locais de morte violenta: investigação pericial e policial, Campinas: Millennium: 2016.

[5] TOCHETTO, Domingos; Criminalística, Campinas: Millennium, 2012.

[6] GONÇALVES, Joanisval Brito; Atividade de Inteligência e legislação correlata, Niterói: Impetus, 2011.

[7] Figueiredo, Isabel S.; Neme, Cristina; Lima, C. S. Loureiro. Homicídios no Brasil: registro e fluxo de informações . Brasília: Ministério da Justiça, Senasp: 2013. (Coleção Pensando a Segurança Pública, V. 1).

[8] Amnésia dissociativa, esquecimento causado por trauma. Acessado em 09/07/2019. Disponível em:

https:/amenteemaravilhosa.com.br/amnesia-dissociativaesquecimento-trauma/

[9] MPSC obtém condenação de responsável por tentativa de homicídio e estupro em Mafra. Acessado

em 10/07/2019. Disponivel em:

https://www.cnpg.org.br/index.php/comunicacaomenu/todas-noticias-cnpg/noticias-mps-estados/39mpsc/5815-santa-catarina-mpsc-obtem-condenacao-deresponsavel-por-tentativa-de-homicidio-e-estupro-emmafra.

[10] Com software que analisa DNA, IGP desvenda crime de 2013 em SC. Acessado em 10/07/2019. Disponivel em: http:/g1.globo.com/sc/santacatarina/noticia/2016/02/com-software-que-analisa-dnaigp-desvenda-crime-de-2013-em-sc.html. 